\title{
Modeling Tidal Characteristics in a Creek-Marsh Drainage System: Implications for Stormwater Management
}

\author{
C. E. Brown ${ }^{1}$ and T. J. Callahan ${ }^{2}$
}

AUTHORS: ${ }^{1}$ M.S. in Environmental and Sustainability Studies, College of Charleston, 66 George Street, Charleston, SC 29424. ${ }^{2}$ Department of Geology and Environmental Geosciences, College of Charleston, 66 George Street, Charleston, SC 29424.

\begin{abstract}
The traditional goal of stormwater management is to reduce the threat of flooding to life and property, and so most landscapes are engineered to maximize the speed at which the unwanted water leaves the watershed. This has been effective in landscapes with some topographic gradient. This often involves the installation of drainage ditches that disperse runoff from urban areas to receiving water bodies; in coastal areas this means a tidal creek, estuary, bay, sounds, or the coastal ocean. This practice reduces flood hazards in some cases but results in unintended effects on the natural hydrology in the watershed and downstream tidal dynamics. For low-gradient watersheds in humid climates, ditch systems also lower the water table of an area, increasing infiltration to recharge and groundwater discharge to streams (baseflow), and larger volume of freshwater delivered downstream yearround. Ditches also create unintentional avenues for the incoming tide from a tidal creek or tidally-influenced waterway to reach further inland, thus reducing the hydraulic gradient between the inland areas and the receiving water body. The combination of these effects can exacerbate compound flooding events, increasing the flood probability if high tide and storm events coincide. Additionally, coastal communities face the challenge of mitigating more complicated flood hazards while land development increases to meet the needs of a growing population.

This study analyzed the tidal influence within an inland drainage ditch in the central coast of South Carolina USA that is representative of thousands of artificially-drained coastal watersheds. The ditch-creek system investigated here is $12 \mathrm{~km}$ long in a 753-hectare (1860-acre) watershed of Church Flats Creek, a first-order tidal system. We monitored for 13 months a $0.75-\mathrm{km}$ reach of the lower ditch portion of the system, just above the relatively undisturbed tidal creek and marsh. Prior to ditching in the 1960s this system had a wetland-rich floodplain but is now partially tidal. Field data collected were stream stage (depth), discharge, tidal range, tidal volume, incoming (flood) and outgoing (ebb) tidal durations, and water table hydrograph at a location about $50 \mathrm{~m}$ of mid-reach of the ditch. Multiple linear regressions were performed to best predict the flood and ebb tidal durations of the system based on tidal characteristics within the ditch. The mean values were $229 \pm 2.5$ and $182 \pm 2.1$ minutes for flood and ebb tide durations, respectively and the models explained 84\% (residual standard error (RSE) of 25 minutes) and $80 \%$ (RSE of 23 minutes) for the flood and ebb conditions, respectively. The models were simulated for sea levels in 1993 and 2050, and results indicate that the flood tide within the drainage ditch is predicted to increase an average of 66 minutes and the total tidal duration (flood and ebb) an average of 139 minutes by 2050. These results suggest a loss in drainage functionality as sea level rises. Increases in the duration of tidal influence will induce a lower capacity for stormwater volume than the drainage infrastructure was constructed to manage, therefore resulting in an increased frequency of compound flooding events because of the lower storage volume and decreased hydraulic gradient in the system. This study fills a knowledge gap of tidal dynamics within coastal ditch-creek systems and we urge stormwater managers to consider the unintended consequences of using traditional stormwater methods in a region that does not benefit from gravity drainage practices like in other regions.
\end{abstract}




\section{INTRODUCTION}

South Carolina's eight coastal counties are home to $27 \%$ of the state's total population, with 1.3 million people contributing over $\$ 21$ billion to the economy in wages alone (NOAA Office for Coastal Management, 2020). The coastal population is expected to increase to over 2 million people by 2025 , with 20 million tourists visiting the coast every year (South Carolina Sea Grant Consortium [SCSGC], 2020). Continued development of coastal areas will result in a higher amount of developed land use, which is expected to result in greater stormwater runoff volume and streams that are "flashier" (faster time-to-peak flow condition, larger stormwater volumes, and reduced stream flow between storms) due to increased storm event runoff and decreased evapotranspiration and infiltration to groundwater (Blair et al. 2014; Semadeni-Davies et al. 2008). Stormwater impacts may be further exacerbated by an increase in frequency of intense rain events, a forecast indicated in global climate models downscaled to the Southeast U.S. region (Wang et al. 2010; Fischer and Knutti, 2015; Lehmann et al. 2015).

\section{STORMWATER INFRASTRUCTURE}

A common practice to convey stormwater runoff along the coast is the use of expansive drainage networks that carry runoff from developed areas to a nearby tidal creek or the coastal ocean. Ditches tend to be straightened and trapezoidal-shaped former ephemeral streams or wetland areas and are designed to move stormwater as quickly as possible to the downstream receiving water body. However, the low topography of the coastal region is less efficient in transporting sediment, causing channel aggradation and reducing the effectiveness of the system on a seasonal basis (Lecce et al. 2006; Magner et al. 2012). Also, climate models suggesting an increase in large storm events may lead to increased stormwater runoff, resulting in a positive feedback effect where ditches and connected creeks continue to straighten due to the increase in peak flow rates and total runoff volume (Gregory et al. 1992; Leopold et al. 2005).

Proper management of drainage systems is also important for water quality impacts, as roadside ditches that empty into larger stormwater systems and coastal creeks accelerate the transport of non-point source pollutants (Buchanan et al. 2013). Like many states, South Carolina has hundreds of water bodies listed as "impaired" on the EPA 303(d) register, with excess sediment concentration the number one reason for all of South Carolina's impaired waters (S.C. DHEC, 2020). The sediment moved in streams can reduce light penetration in the water column and affect photosynthesis, large concentrations of sediment in a stream can change the water temperature regime, and excess sediment deposition can bury or otherwise affect macroinvertebrates and their habitats in waterways (Gray and Ward 1982; Poole and Berman 2001; Izagirre et al. 2009). Furthermore, larger volumes of runoff can transport pollutants from developed or agricultural areas and deliver those materials to surface waters while bypassing natural degradation incubators such as floodplains and wetlands (Koch and Gobler 2009; Buchanan et al. 2013). First-order, intertidal creeks in particular have been heavily affected by the increase in non-point source pollutants associated with increased urban development (Sanger et al. 2015).

\section{TIDAL CREEK MORPHOLOGY AND HYDROLOGY}

Tidal creeks along the South Carolina coast are semidiurnal, meaning there are two high and low tides in a lunar day; a typical tidal cycle (flood and ebb tide) lasts around 12 hours and 25 minutes. Tidal creeks are recognizable by having long, meandering networks that are longer and wider than their terrestrial counterparts (Myrick and Leopold 1963; Novakowski et al. 2004). The increased width in tidal creeks is due to the relatively short duration of maximum discharge in the system during peak ebb and flood tides, which prevents the creeks from reaching a deeper equilibrium (Fagherazzi and Furbish 2001). The wider, shallower beds of tidal creeks are typically $\mathrm{U}$-shaped or asymmetrical in profile (Perillo 2009), which is a stark contrast to the straight, trapezoidal shape of drainage ditches that are connected to their headwaters.

As tidal creeks move inland to lower-order creeks, they have an exponential decrease in width in the upstream direction, which increases the friction of the system and dissipates tidal energy (Novakowski et al. 2004). For small first-order tidal creeks, upstream locations commonly end in an inland floodplain or marsh. These creeks are thereby responsible for the majority of water, nutrient, and sediment fluxes between the ocean and marshes (Fagherazzi et al. 2008), and the introduction of drainage ditches that interrupt these systems can therefore alter this exchange.

\section{SEA LEVEL RISE AND COMPOUND FLOODING}

Continued sea level rise (SLR) is also a threat for drainage infrastructure in any barrier or sea-island community. Charleston sea level has risen by 0.332 meters in the past century (NOAA Tides and Currents 2019), and there has been an increase in the acceleration of global sea level rise since 1993 (Church and White 2006; Merrifield et al. 2009). Installed drainage infrastructure can act to intensify the effects of SLR, as ditches attached to tidal creeks act as conduits to the incoming tide and exhibit bidirectional flow similar to natural tidal creeks; this can increase inland flooding during storm events (Poulter et al. 2008).

As sea level rises there is a reduction in the level of freeboard gap in coastal creeks, as the distance between mean sea level and the flood threshold of creeks is lowered (Sweet and Park, 2014; Moftakhari et al. 2015). The problem 


\section{Modeling Tidal Characteristics in a Creek-Marsh Drainage System}

of increased flooding could be further exacerbated by the fact that aggradation occurs in low gradient coastal drainage ditches, which can further flatten the hydraulic gradient and thereby increase the residence time of stormwater in the system (Magner et al. 2012; D’Ambrosio et al. 2015). The bidirectional tidal flow in combination with the fluvial inland stormflow is likely to increase the flood probability of areas, especially with the consideration of SLR (Moftakhari et al. 2017). The interactions between tidal flow and stormflow have resulted in an increase in nuisance flood events (defined as nondestructive flooding), which is expected to increase in frequency by $55 \%$ by 2050 (Moftakhari et al. 2015). Tidal creek-drainage ditch systems may be especially vulnerable and experience increased likelihood of these events due to the alterations of natural systems.

\section{STUDY PURPOSE}

The purpose of this study was to fill an existing knowledge gap on the hydrology and tidal dynamics within stormwater drainage infrastructure connected to tidal creeks, as well as how that tidal influence may change in the future with increased sea level rise. This information will be useful for land managers and stormwater engineers in designing resilient and sustainable infrastructure to mitigate the combined effects of tidal and stormwater flooding in the future. This information will also be useful for government organizations looking to identify vulnerable areas that could benefit from restoration and/or alternative approaches to stormwater management.

\section{METHODS}

\section{STUDY SITE}

The location for this project was the central coast of South Carolina USA, in southwestern Charleston County near the town of Hollywood (Figure 1). Due to property access limitations, only one ditched tidal creek system was monitored for this study. Based on qualitative observations of satellite imagery we estimated several hundred similar tidal creeks have been affected by similar stormwater management infrastructure as well as the influence of more than 20,000 stormwater ponds in the coastal counties of South Carolina (Cotti-Rausch et al. 2019). The focus of this project was a drainage ditch that was improved sometime between February 1989 and February 1994 (Figure 2), most likely after Hurricane Hugo, which was a Category 4 storm when it made landfall in South Carolina in September 1989. The date of construction of the ditch is unknown but residents in the area estimate that to be the 1960s. The ditch carries stormwater from Hollywood, a town of about 5,000 residents with a small town center to Church Flats Creek, a first-order tidal stream. Church Flats Creek has a confluence with the Stono River approximately 1.6 river $\mathrm{km}$ downstream of the terminus of the drainage ditch into the headwaters of the creek and salt marsh system (dominated by Spartina alterniflora with Juncus roemarianus vegetation).

Church Flats Creek drains a 753-hectare (1860-acre) watershed and has its outlet at the Stono River. The drainage ditch length is $12.0 \mathrm{~km}$ before reaching its confluence with the headwaters of the creek and drains 621 hectares (1535

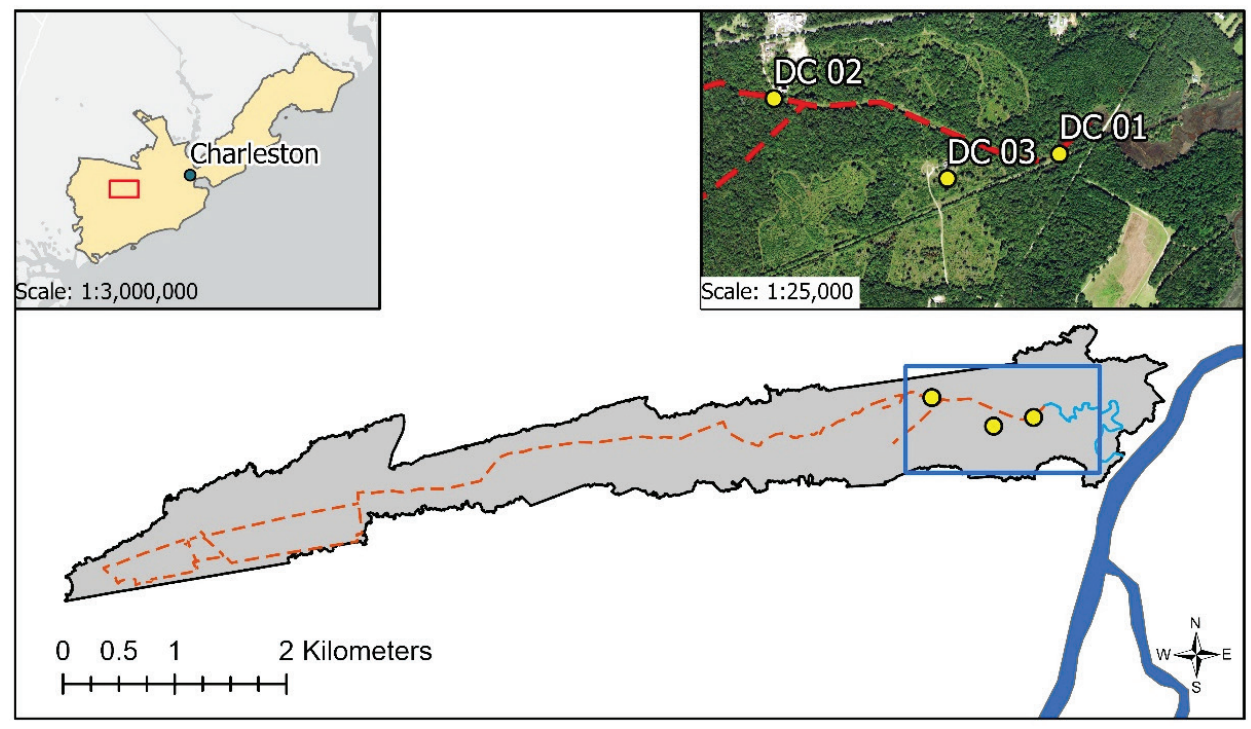

Figure 1. Study location of the Church Flats drainage ditch creek system. Church Flats watershed is $30 \mathrm{~km}$ southwest of Charleston, SC (upper left inset map) and is 750 hectares in area. The natural portion of Church Flats Creek can be seen in light blue on the large map and the artificial drainage ditch that has been installed is seen in dotted red. The monitoring locations can be seen in the upper right inset map. The DC 01 and DC 02 locations were in the drainage ditch; DC 01 was $100 \mathrm{~m}$ upstream of the natural headwaters of the creek and DC 02 was $750 \mathrm{~m}$ upstream of DC 01. The DC 03 location was a shallow well about $3.5 \mathrm{~m}$ deep that recorded the water table position near the ditch. 

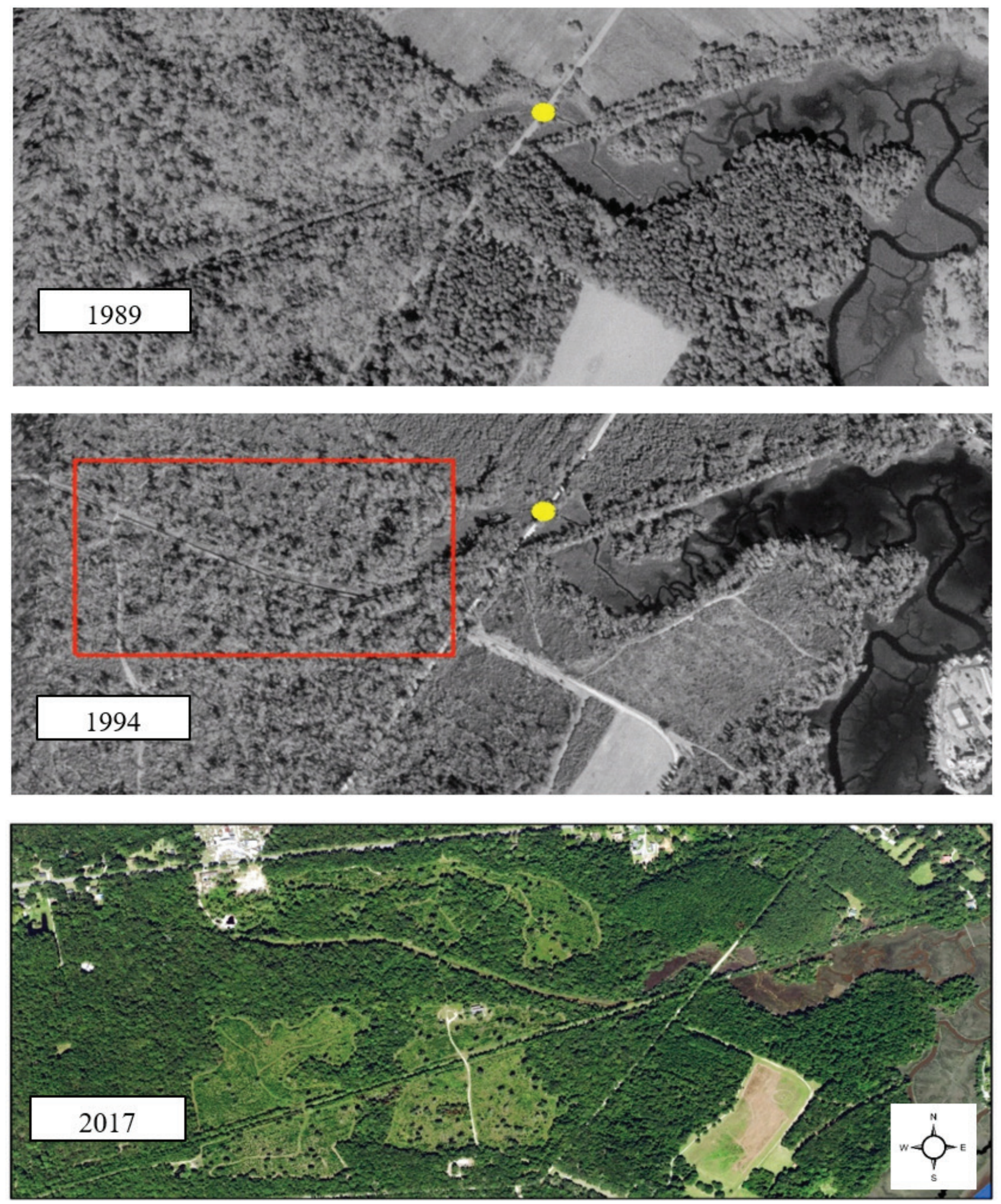

Figure 2. Satellite imagery of the Church Flats Creek study site on Stono Preserve from 1989 to 2017. The natural headwaters of the creek were directly upstream of the yellow dot, which was the intersection of the creek with Dixie Plantation Road. The installed drainage ditch can be seen within the red rectangle in the 1994 photo, with the most recent photography displaying how the drainage ditch was installed through wetlands to carry runoff to the headwaters of Church Flats Creek. Image sources: Google Historical Imagery. 


\section{Modeling Tidal Characteristics in a Creek-Marsh Drainage System}

acres) of the total Church Flats watershed. The Church Flats Creek and ditch system has two major flow restrictions which act to partially restrict both the bidirectional tidal flow and the stormflow from the upstream locations (Figure 2). The Church Flats drainage system is not included in the National Hydrography Dataset (NHD), highlighting the importance of ground-truthing topography when constructing hydrological models, especially in areas where drainage infrastructure is present.

\section{WATERSHED CHARACTERISTICS}

The area within the watershed is very rural compared to the nearby urbanized Charleston, with $2.01 \%$ impervious cover within the watershed (NOAA C-CAP, 2010; determined using methodology from Blair et al. 2014). The majority of land within the watershed is forested wetland (29\%) and evergreen forest (26\%); overall wetlands make up $41 \%$ of the total watershed area. The dominant soil type of the area is Wadmalaw, which is a loamy, hydric soil that has minimal slope. The soil is defined as being poorly drained with a water table that is near the surface for up to six months of the year. The majority of the soil within the entire watershed is of the hydrologic type A/D (68\%), which indicates that it would be well-drained soil if not for the shallow water table (SSURGO database [date unknown]). The shallow water table of the coastal plain suggests that we expect to see baseflow to surface water bodies including the drainage ditch year-round.

The drainage ditch that connects to Church Flats Creek was straight and mostly trapezoidal in cross-sectional shape, similar to the hundreds of drainage ditches in this region. Ditches are engineered to relay stormwater as quickly as possible to a downstream receiving water body (in this case a tidal creek). It is also more cost-effective than creating stormwater conveyances or storage resources that employ the natural conditions or ecosystem services in these watersheds. The ditch was constructed through and adjacent to wetlands, which account for $41 \%$ of the entire watershed, and it is possible the ditch has experienced larger peak flow rates from storm events than if the wetlands were not connected to the active surface drainage system of the ditch (Buchanan et al. 2013). The downstream portion of Church Flats Creek was a natural first-order tidal creek with a sinuous, meandering morphology and a floodplain salt marsh consisting of Spartina alterniflora (smooth cordgrass) with some patches of Juncus roemarianus (black needlerush) as is common in this region.

\section{HYDROLOGIC MONITORING LOCATIONS}

Three locations were chosen to monitor hydrologic conditions within the Church Flats system: two locations within the drainage ditch, DC 01 ( $0.34 \mathrm{~m}$ above sea level [asl]) and DC 02 $(1.39 \mathrm{~m}$ asl), and one location to monitor the local water table, DC 03 (2.93 m asl; Figure 1). The first monitoring location,
DC 01 , was located about $100 \mathrm{~m}$ upstream of the start of the tidal creek and salt marsh condition ("headwaters") of Church Flats Creek at the landscape position where the incoming tide would have naturally dispersed into the floodplain before the ditch was installed. This location was chosen to observe the tidal influence within the drainage ditch from the downstream tidal creek. The second monitoring site, DC 02 , was located another $0.75 \mathrm{~km}$ upstream of DC 01 and was chosen to monitor streamflow and stormflow that was not directly influenced by the tide. The water table monitoring station, DC 03 , was located $150 \mathrm{~m}$ west of site DC 01 at a point of relatively high elevation for the system, near the watershed divide.

A stilling well (screened standpipe) was installed in the middle of the drainage ditch at each of the DC 01 and DC 02 locations. Locations were chosen where the channel was straight for at least $30 \mathrm{~m}$ upstream and downstream of each site. The water table position was monitored at DC 03 , with pressure transducers with a datalogger at each site set to record at 30-minute intervals (Solinst, Inc., Georgetown, Ontario). Barometric compensation was conducted using barometric data collected at the site. The study period reported here was January 17, 2019 - February 5, 2020.

\section{DETERMINING DATUM FOR TIDE DURATION CALCULATIONS}

The time of high-water slack (HWS); that is, when stream water velocity is zero (not necessarily high tide condition of deepest water) was used as a datum within each tidal cycle to measure the duration of the flood and ebb tides. In order to properly calculate the time of HWS for each tidal cycle throughout the observation period at an ungauged site, a relationship was determined between the delay in the time of HWS at the DC 01 study site and time of high tide (HT) at the nearby NOAA Church Flats, Stono River station (\#8665763). The delay determined through this model was then added to each HT cycle at the NOAA gage to predict the time of HWS at DC 01 for every tidal cycle across the observation period. Model creation was based on direct observations of HWS at DC 01.

\section{DRAINAGE DITCH RESPONSE TO MULTIPLE INPUTS}

The impacts of multiple hydrologic inputs within the drainage ditch has created a system in which flood occurrence is more difficult to predict. The bidirectional flow of the drainage ditch from the tidal influence, along with the local water table level and stormflow from the upstream location work in conjunction to determine the stage response of the ditchcreek system. The importance of these separate factors, especially the baseflow and tidal influence, can be seen in the hydrographs for storm events from April and September 2019 (Figures 3 and 4; Table 1). Tidal influence creates a reduction in the level of freeboard gap in the system that will 

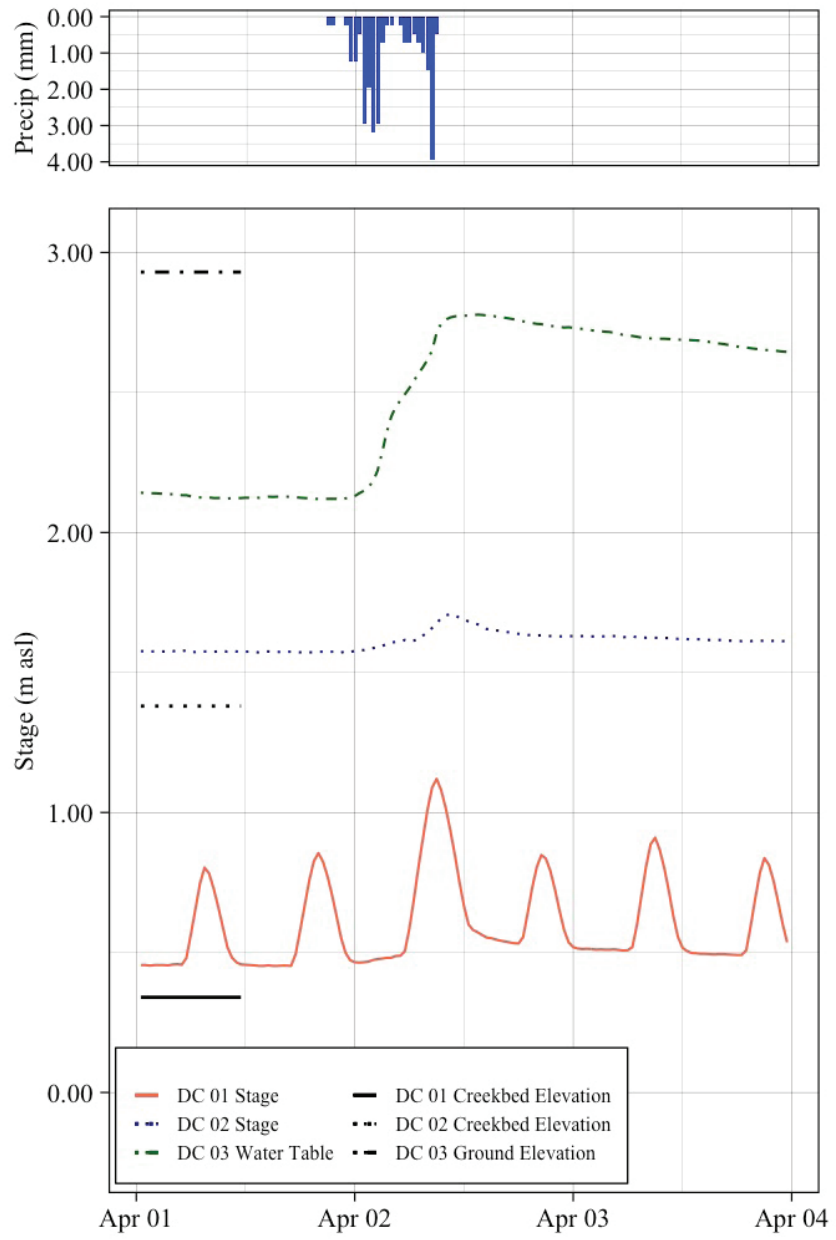

Figure 3. Hydrograph for the April 2, 2019 storm event. At top is the hyetograph from the event, showing the amount of precipitation in 30-minute increments. The bottom chart shows the stage at the tidally influenced DC 01 site and the non-tidal DC 02 site. The DC 03 water table monitoring location is $150 \mathrm{~m}$ west of $\mathrm{DC} 01$. Horizontal lines at left in the chart show the ground elevation for reference (stream bed for DC 01 and DC 02, and ground surface for DC 03).

likely result in flood stage being reached with lower inputs from separate sources.

\section{DISCHARGE MEASUREMENTS AT DC 01}

Discharge measurements were taken across tidal cycles at DC 01 in order to determine the tidal volumes and the time of HWS of each observed tidal cycle. Velocity measurements were taken across the cross-section of DC 01 using a current meter (Marsh-McBirney FloMate 2000; Hach Company, Loveland, CO USA) and a wading rod at $10 \%$ width across the stream. The total discharge of the ditch at time of measurement was calculated using Equation 1, where $\mathrm{Q}=$ discharge $\left(\mathrm{m}^{3} / \mathrm{s}\right), \mathrm{V}=$ velocity $(\mathrm{m} / \mathrm{s})$ and $\mathrm{A}=$ cross-sectional area $\left(\mathrm{m}^{2}\right)$ (Brooks et al. 2013).

$$
Q=\sum_{1}^{n}\left(V_{i} A_{i}\right)
$$
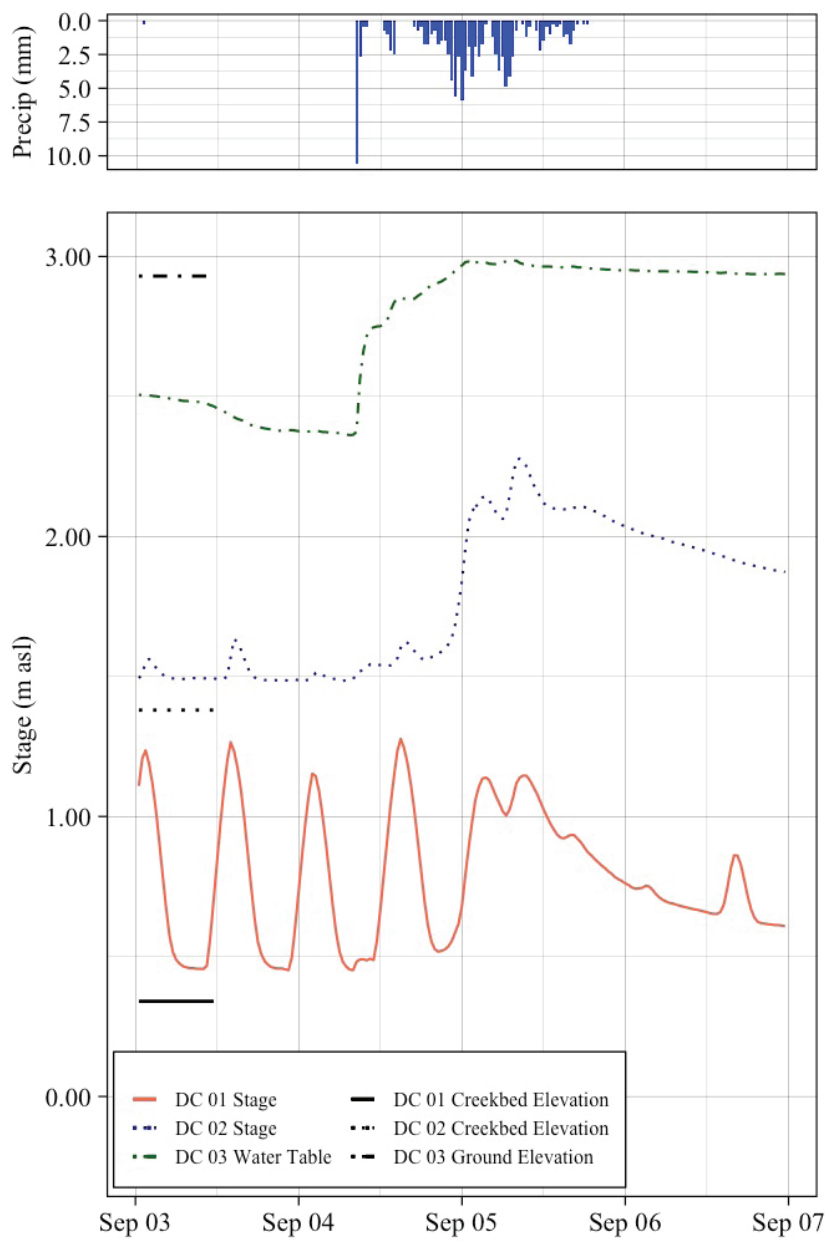

Figure 4. Hydrograph for the September 4, 2019 (Hurricane Dorian) storm event. At top is the hyetograph from the event, showing the amount of precipitation in 30-minute increments and the bottom chart shows the stage at the tidally influenced DC 01 site, and the normally non-tidal DC 02 site. This was one of the only instances where tidal influence was recorded at DC 02 throughout the observation period due to the extreme tidal ranges. The DC 03 monitoring location is 150 west of DC 01 and shows the levels of the water table for the area. Horizontal lines at left in the chart show the ground elevation for reference (stream bed for DC 01 and DC 02, and ground surface for DC 03).

\section{DETERMINING THE TIME OF HIGH WATER SLACK TIDE AND TIDAL VOLUMES}

Discharge measurements were taken at 30-minute intervals across tidal cycles. Outgoing flow (ebb tide or baseflow) was characterized by having a positive discharge; the incoming tide had negative discharge. The time of low water slack (LWS) tide was defined as the point where discharge within the ditch was equal to $0 \mathrm{~m}^{3} / \mathrm{s}$ when the tide condition changed from outgoing (positive discharge) to incoming flow (negative discharge). LWS was determined by interpolating the time where discharge was equal to $0 \mathrm{~m}^{3} / \mathrm{s}$ between measurements of outgoing and then incoming discharge observations. The time of high water slack (HWS) tide was similarly calculated 


\section{Modeling Tidal Characteristics in a Creek-Marsh Drainage System}

Table 1. Storm event characteristics for the hydrographs included from April 1 and September 4, 2019. The reaction of the monitoring stations are shown in Figures 3 and 4 . The 24 hour and 120 hour prior precipitation totals and the initial water table depth represent the antecedent moisture condition of the system.

\begin{tabular}{cccccc}
\hline Storm Event & Total Storm Depth $(\mathbf{m m})$ & Storm Volume $\left(\mathbf{m}^{3}\right)$ & $\begin{array}{c}\text { 24-hr Prior } \\
\text { Precipitation }(\mathbf{m m})\end{array}$ & $\begin{array}{c}\text { 120-hr Prior } \\
\text { Precipitation }(\mathbf{m m})\end{array}$ & $\begin{array}{c}\text { Initial Water Table } \\
\text { Depth }(\mathbf{m} \text { bgs })\end{array}$ \\
\hline $04 / 01 / 2019$ & 25.8 & 160083 & 25.77 & 26.51 & 0.81 \\
$09 / 04 / 2019$ & 106.5 & 661762 & 20.62 & 35.84 & 0.57 \\
\hline
\end{tabular}

at the point where discharge was equal to $0 \mathrm{~m}^{3} / \mathrm{s}$ from where the tide changes from incoming to outgoing. Flood tide volumes were calculated using the discharge values from the time of LWS to HWS.

\section{CALCULATING FLOOD AND EBB TIDE DURATIONS}

Each 30-minute water depth (stage) observation at DC 01 was assigned the value of either "baseflow" or "tidal" depending on the change in stage between observations. A threshold of $1 \mathrm{~cm}$ was used; if a reading had less than a $1-\mathrm{cm}$ change in stage from both the prior and following 30-minute stage readings in between instances of HWS, then it was assumed the tidal volume had left the system and returned to baseflow levels seen prior to the previous flood tide, otherwise it was classified as tidal. The $1-\mathrm{cm}$ threshold was used to account for possible inaccuracies with the datalogger readings, which are accurate to $\pm 0.005 \mathrm{~m}$.

Flood tide duration was defined as the time from the first tidal signal after baseflow to the time of HWS, and ebb tide duration was defined as the time from HWS to the last tidal signal prior to baseflow for each tidal cycle over the observation period.

\section{CREATING MODELS TO PREDICT TIDE DURATION}

Relationships between tidal variables and the incoming and outgoing tide durations were observed; a multiple linear regression model was built within the statistical software $R$ (R Core Team, 2017) to predict the flood and ebb tide durations. Tidal variables explored in relation to the tidal durations were the season; the maximum stage, baseflow stage, and range of the tidal cycle; and the high tide factor (high tide [HT] versus higher high tide [HHT]). Seasons were defined in 3-month intervals following the meteorological seasons, for example, winter is December through February. Multiple linear regressions were performed for both the ebb and flood tidal durations to determine the best model fit from the above factors. Any observations of tidal condition when there had been precipitation within the previous tidal cycle were not used in these calculations due to the likelihood of stormwater runoff within the system. After excluding the observations where precipitation occurred, there were 610 tidal cycles used in this analysis. Predictive models of flood and ebb durations were created using a training group (80\% of the total dataset that was randomly selected) and the fit of the models were tested using the remaining $20 \%$ of the data. Multiple linear regressions were performed using the above tidal variables to determine the best predictive models for the flood and ebb tidal durations through stepwise analysis, with the best model determined through $\mathrm{R}^{2}$ and the residual standard error (RSE) of the model. The Akaike Information Criterion (AIC) was used to determine the predictive model that best fit the concept of parsimony (Hooper et al. 2008).

APPLYING PREDICTIVE MODELS TO FUTURE SEA LEVEL RISE The flood and tide duration observations were altered according to predictions of SLR in order to simulate how these durations may change under different climate scenarios. For this analysis, we backcast conditions to 1993 by assuming the area had undergone the global average of SLR since that time (0.096 m; NASA, 2019) and forecast conditions to 2050 assuming a moderate prediction of $0.422 \mathrm{~m}$ of SLR by that time (SeaLevelRise.org). To simulate these tidal durations, the observations of the maximum stage and the tidal range were altered by the respective amount of SLR (-0.096 $\mathrm{m}$ for the 1993 scenario and $+0.422 \mathrm{~m}$ for the 2050 scenario), with the other tidal variables in the duration models remaining constant (the high tide cycle factor, the seasonal factor, and the baseflow stage). The high tide cycle and seasonal factors were kept constant because these variables will be unaltered by SLR, and the baseflow stage was kept constant because we assume that the system will still return to baseflow between tidal cycles in the future since it is a partially tidal system. However, it is expected that these assumptions likely create a conservative bias within the model predictions. For analysis, the model predictions of the current conditions (2019) were used instead of the observations for consistency in comparison across SLR scenarios.

\section{RESULTS AND DISCUSSION}

\section{DETERMINING TIME OF HIGH WATER SLACK} TIDE USING STREAM STAGE DATA

There were 12 observations of high water slack (HWS) tide condition at the DC 01 monitoring location determined through tidal discharge measurements. The tidal range at DC 01 was determined to be the best predictor of the delay in 
HWS at DC 01 from the NOAA Church Flats Gage, with an $\mathrm{R}^{2}$ value of 0.42 , residual standard error (RSE) of 19 minutes, and a p-value of 0.01 . This relationship was used to predict the time of HWS for every tidal cycle in the observation period to be used as the datum for calculating flood and ebb tidal durations. Observations indicate that baseflow is likely a significant factor in the time of HWS, but due to the small number of observations a model with multiple independent variables wasn't evaluated to avoid overfitting.

\section{TIDAL INFLUENCE: FLOOD TIDE VOLUMES}

\section{IN THE DRAINAGE DITCH}

There were 9 complete flood tidal cycles observed at the monitoring site DC 01 , with tidal volumes ranging from 53 to $556 \mathrm{~m}^{3}$, with the average flood tide having a volume of 279 $\pm 54.7 \mathrm{~m}^{3}$. The observed tidal range was the best predictor of the flood tide volume ( $\mathrm{R}^{2}$ value of 0.54 and $\mathrm{p}$-value of 0.02 ), but the baseflow stage of the ditch was also likely a significant factor, as its $\mathrm{p}$-value was $\leq 0.05$. A simple linear model was used in place of a multiple linear regression due to the small number of observations and to prevent overfitting, but it is likely that baseflow has a significant impact on the flood tide volume within the ditch, as the incoming tide would need to reverse the gradient of the system before moving upstream. Further research should focus on how both the tidal range of the cycle and the baseflow stage interact to affect the volumes of the flood tides entering the system.

\section{TIDAL INFLUENCE: TIDAL CHARACTERISTICS} WITHIN THE DRAINAGE DITCH

Monitoring site DC 01, an area that was originally a floodplain, saw an average tidal range of $0.423 \pm 0.008 \mathrm{~m}$, with a maximum range of $0.898 \mathrm{~m}$ over the observation period. The average flood tide duration was $229 \pm 2.5$ minutes and the average ebb tide duration was $182 \pm 2.1$ minutes. These observations fit previous findings that the ebb tide is dominant in the Southeastern United States, defined as having a shorter duration and larger peak discharge values than the flood tide (Ellis et al. 2017; Boone, 1975). These findings indicate that newly tidal ditch-creek systems with an unnatural upstream geomorphology adhere to the same patterns as naturally tidal systems in coastal South Carolina.

The observations of both the flood and ebb tides were largely normal in distribution (Figure 5-A and 5-B). Observations of tidal range and the max stage per tidal cycle had bimodal tendencies, which is likely due to the pattern of semidiurnal tides, where there is a higher high tide and a lower high tide within a single lunar day (Figure 5-C and 5-D).

The observations of baseflow throughout the monitoring period were highly skewed, with the majority of the observations occurring on the lower end of values (Figure 5 -E). This skewness is likely due to the effect of seasonality on baseflow levels within the ditch (Figure 6). Observations show that the highest observed baseflow levels were in the
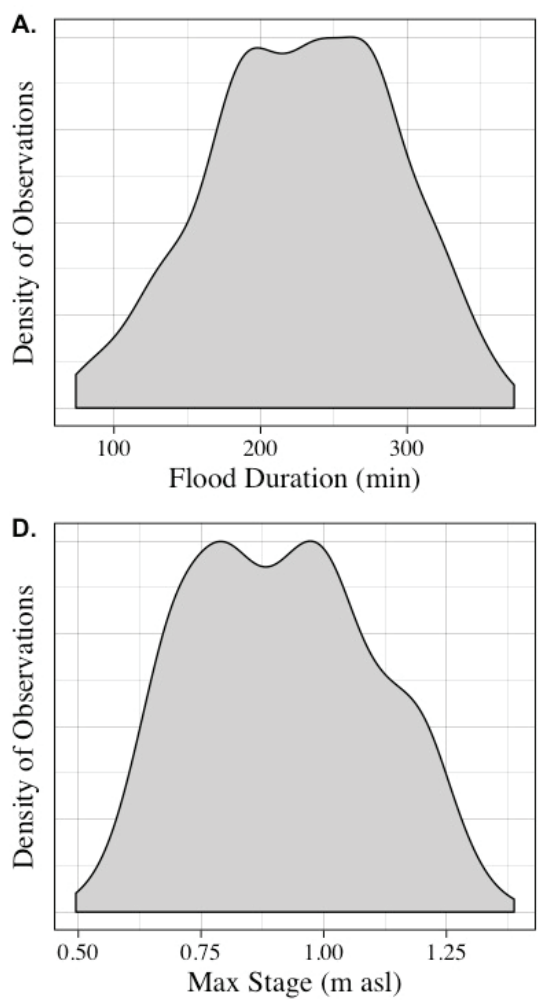

B.

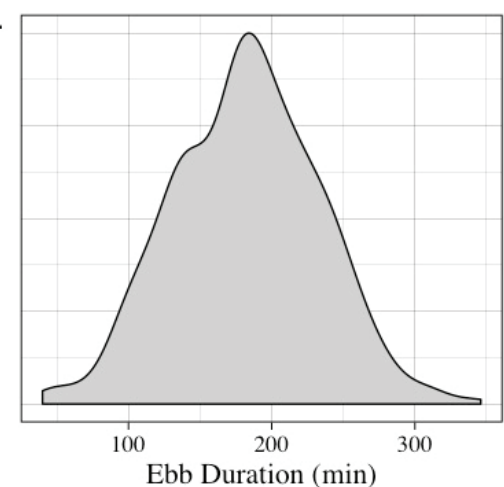

E.

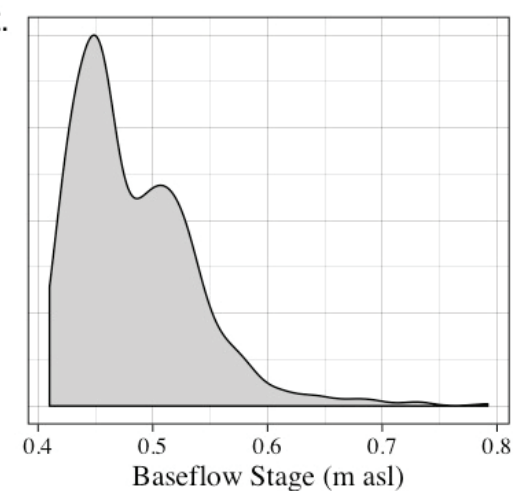

c.

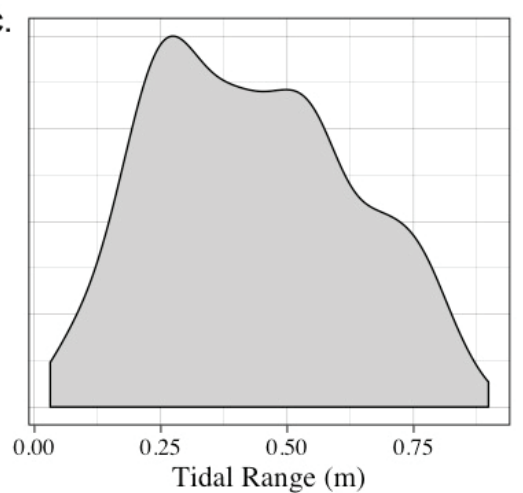

Figure 5. Observations of tidal characteristics at the DC 01 monitoring site during the observation period from January 2019February 2020. A total of 610 tidal cycles were included in these observations. 


\section{Modeling Tidal Characteristics in a Creek-Marsh Drainage System}
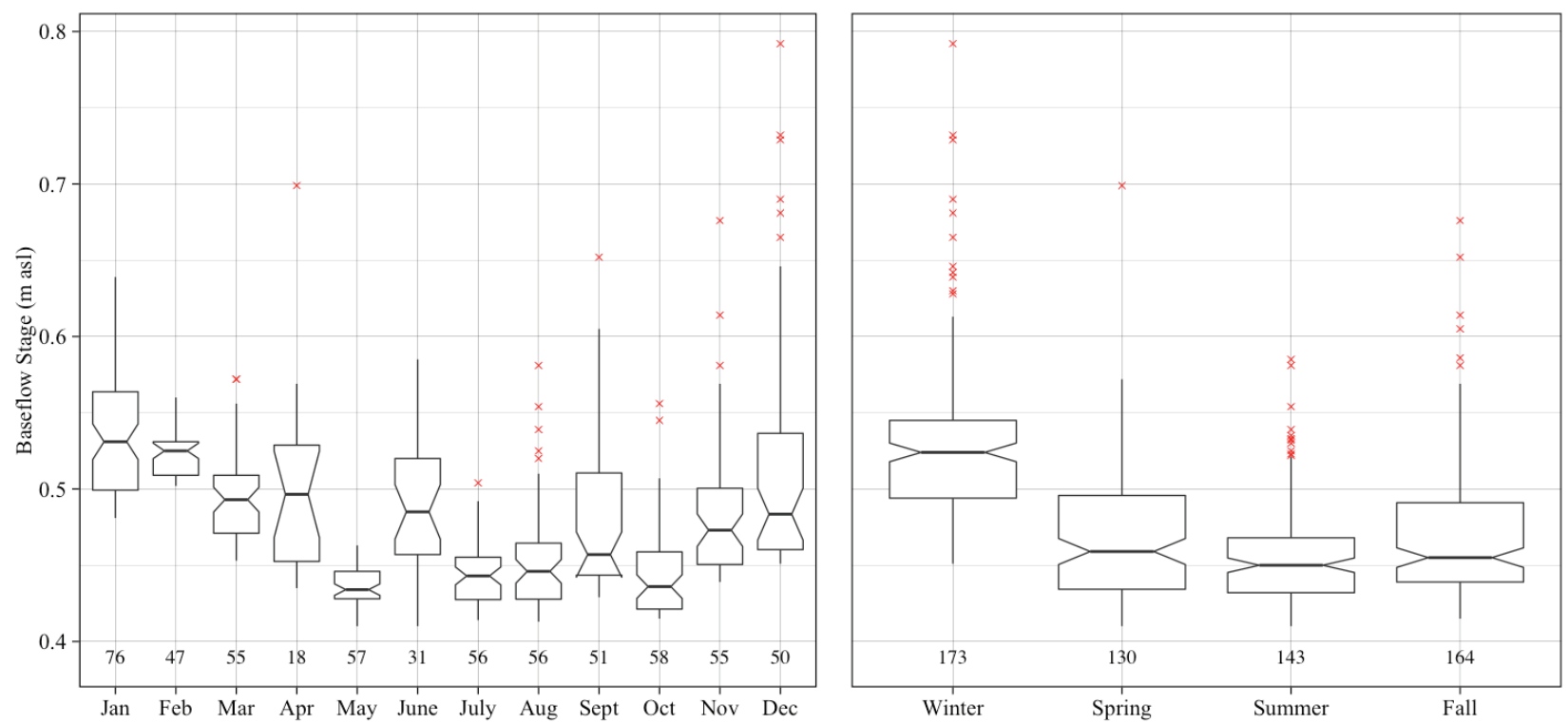

Figure 6. Observations of baseflow levels at DC 01. These baseflow levels (groundwater discharge to the stream) were grouped according to the month (left) and the meteorological season (right). The horizontal "waist" of each box represents the median value, and the height of the box shows the range from first to third quartiles. The vertical bars (whiskers) represent the maximum and minimum values. Outliers were values 1.5 times larger than the interquartile range (first-third quartiles) and are noted here as red asterisks. Seasons were defined as follows: winter: December-February; spring: March-May; summer: June-August; and fall: September-November. The total number of observations for each month or season are on the bottom of the graphs.

winter months, which is when evapotranspiration (ET) rates are at the lowest (Dolan et al. 1984), indicating that there is increased baseflow in the ditch from groundwater discharge. There was a sharp drop in baseflow levels as "leaf-out" occurred in the spring and continued through the summer months, with June and September not fitting the expected trend. The increase in baseflow in June was likely due to a combination of a storm event and a lack of data, as roughly one-half of the stage recordings were lost due to the destruction of the stilling well from debris. The increase in baseflow in September was likely due to the intense rainfall from Hurricane Dorian.

\section{TIDAL CHARACTERISTICS WITHIN THE CHURCH FLATS DRAINAGE SYSTEM}

Each tidal characteristic that was used within the multiple linear regressions was first modeled independently (Figure 7). The time of the flood tide duration was most influenced by the tidal range of the cycle (Figure $7-A ; R^{2}$ of 0.66 ) and the ebb duration was most influenced by the maximum stage of the cycle (Figure 7-D; $\mathrm{R}^{2}$ of 0.73 ). All of the relationships explored had significant $\mathrm{p}$-values except for the influence of the baseflow stage on the ebb tide duration, which had a p-value of 0.25 (Figure 7-F).

The influence of the baseflow stage in relation to the flood and ebb tidal durations was as expected. The negative correlation between baseflow stage and the flood tide duration was due to the opposing forces between baseflow leaving the system and the incoming tide reversing the hydraulic gradient; the higher the baseflow stage (and therefore baseflow volume), the shorter the duration of the incoming tide. There was no correlation between the ebb tide duration and the baseflow stage of the cycle because the system returned to baseflow only after the entirety of the tidal volume exited the system.

The factorial variables that were analyzed, the high tide cycle and the season, both had relatively low $\mathrm{R}^{2}$ values in terms of predicting the flood and ebb tide durations (Figure 7-G through J). While the correlative values for these factors were low, the p-values were significant for each of these relationships and the tidal variables were therefore included in the stepwise analysis used to find the best multiple linear regression model.

\section{MODEL RESULTS TO PREDICT TIDAL DURATION}

Models were created using the training set of data, and then those models were applied to the test set data (Figure 8). The RSE values of the model-applied test set predictions are lower than the RSE values of the training set and the $\mathrm{R}^{2}$ values represent a goodness of fit (Table 2), indicating that the multiple linear regressions are good predictors of the flood and ebb tidal durations observed. Both models do appear to underestimate the maximum duration of the respective tidal cycles compared to observations (Table 3 ).

The tidal range of the cycle and the maximum stage observed were tested for co-linearity, which returned a value 

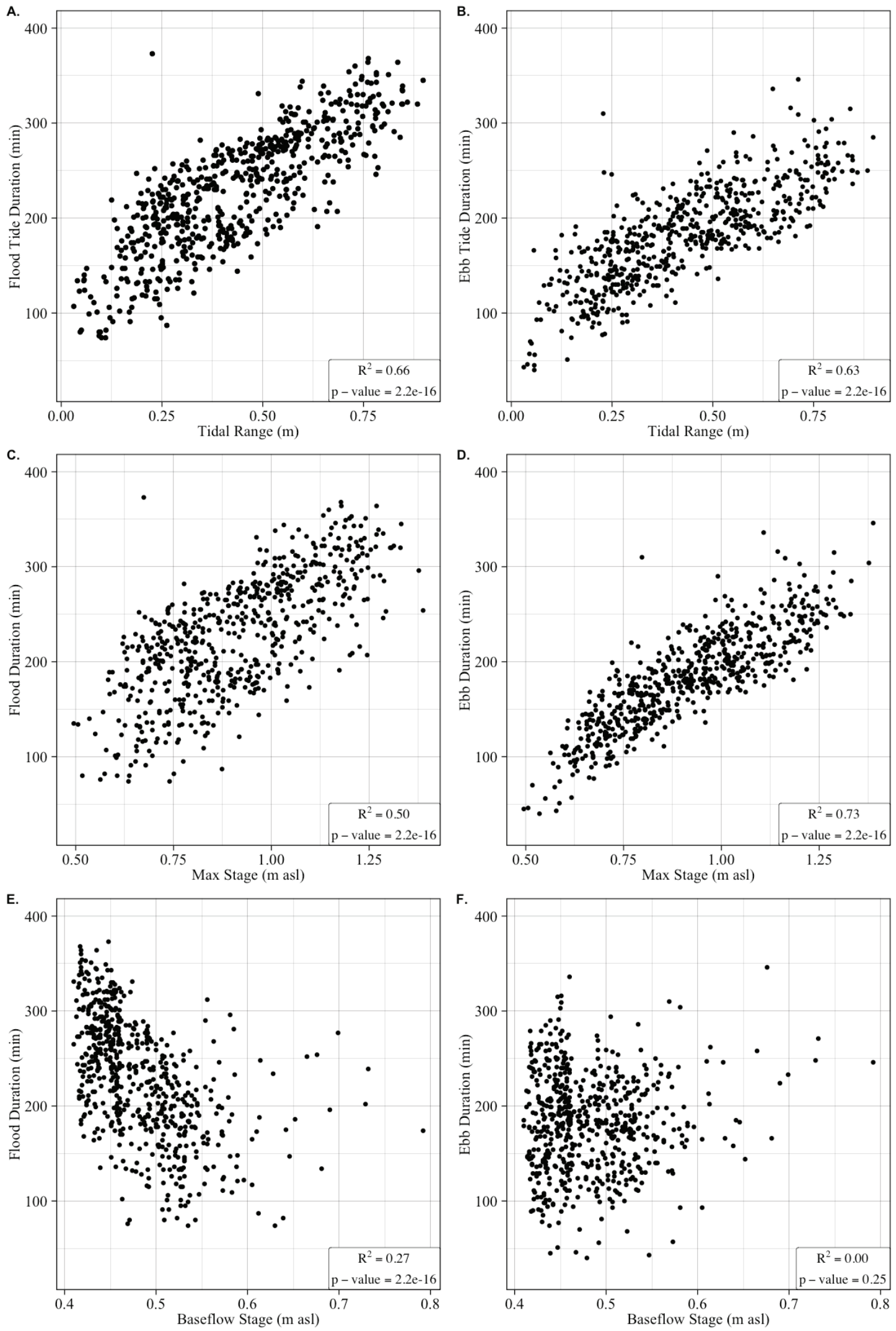

Figure 7. Individual relationships between observed tidal characteristics and the durations of the flood (left column) and ebb tide (right column) durations (plots A-F). These relationships were used within a multiple linear regression to predict the durations of the flood and ebb tides at DC 01. For the categorical variables observed (the high tide cycle and the season; plots G-J), the horizontal "waist" of each box represents the median value, and the height of the box shows the range from first to third quartiles. The vertical bars (whiskers) represent the maximum and minimum values. Outliers were values that were a value larger than 1.5 times the interquartile range (first-third quartiles) from the quartiles and are noted here as red asterisks. 
Modeling Tidal Characteristics in a Creek-Marsh Drainage System
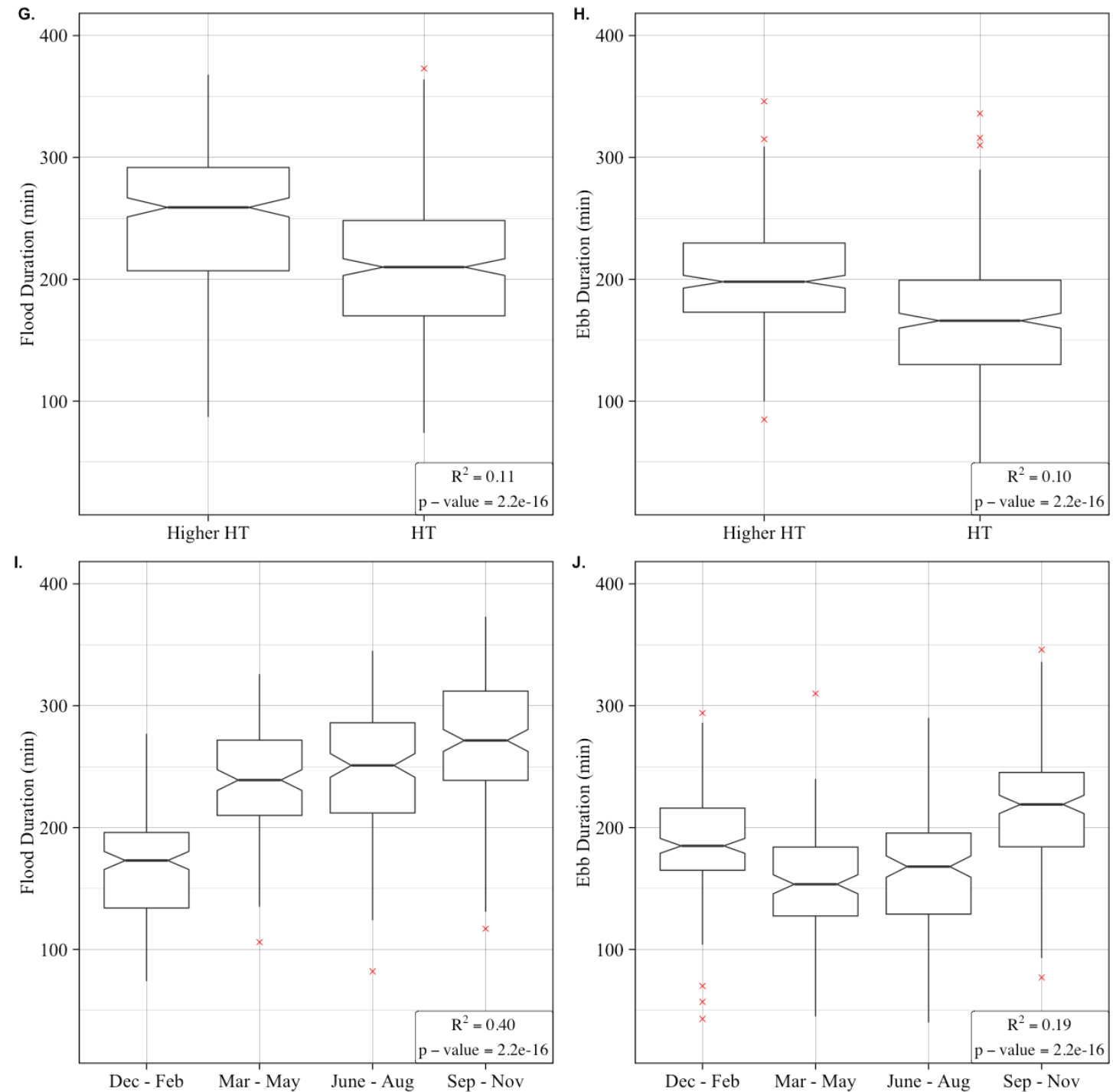

Figure 7. (continued)

$>0.9$ (with a maximum of 1). Instead of excluding one of the variables, both were included due to the dependence of the tidal range on both the maximum stage and the baseflow stages of the cycle. Multiple models were examined including those without the tidal range or max stage included, but the AIC values indicated models that included both tidal range and the maximum stage as the best fit, with the residuals of the models meeting the assumptions of being normally distributed.

The RSE values returned from the flood and ebb duration models ( 25 and 23 minutes, respectively) represent good model fits in relation to the error associated with the observation measurements. Due to the dataloggers taking readings at 30-minute intervals, the baseflow and tidal cycles were estimated to the nearest 30-minute mark. The time of HWS was also estimated for each tidal cycle in this analysis, with the RSE of the model estimation being 19 minutes. Improving the estimation of HWS for individual tidal cycles, either by direct discharge estimation or by an improved model with multiple independent variables, and increasing the recording intervals of the dataloggers to 15 minutes would likely result in better model fits in the future.

\section{APPLYING TIDE MODELS TO SEA LEVEL RISE SCENARIOS}

Application of past and predicted future sea level changes indicate that the tidal influence has and will continue to change within the drainage ditch (Figure 9). Both the flood and ebb tide durations have increased since 1993, with the flood and ebb tides both having increased on average by 19 and 23 minutes, respectively. The flood tide is expected to increase in duration by 66 minutes and the ebb tide is expected to increase by 73 minutes in the 2050 scenario (Table 4). Overall, these predictions result in the current total tidal influence (ebb and flood tide) within the drainage ditch increasing from 412 minutes to 551 minutes. A typical complete semidiurnal tidal cycle will take approximately 745 minutes to complete (half of a lunar day), so these predictions 


\section{Brown, Callahan}
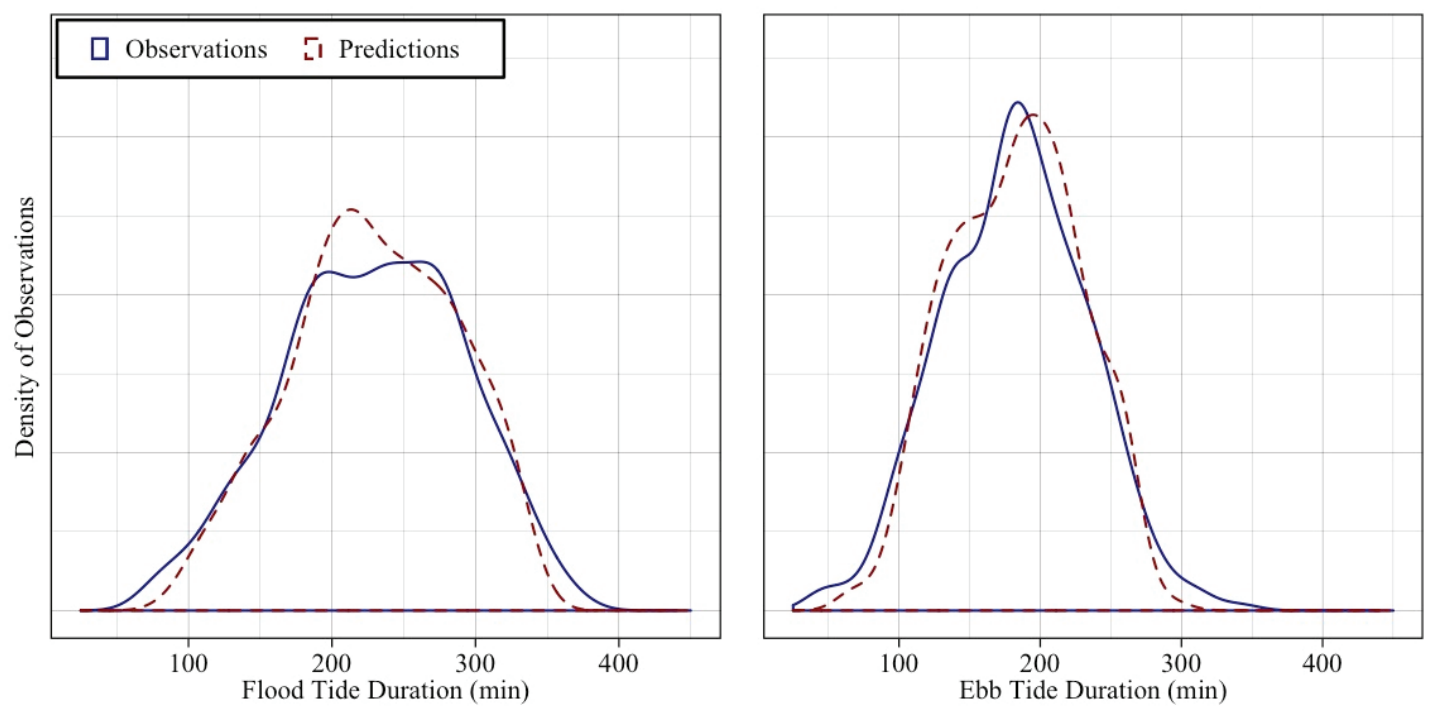

Figure 8. Comparison of tidal duration model predictions vs observations. The multiple linear regression model predictions are seen in the dashed red line and the observations are the solid blue line. The training set of data ( $80 \%$ of observations randomly chosen) was used to create these models, and the results above show the predictions and observations from the test set of data (remaining $20 \%$ of observations) that the model was applied to. As seen, the predictions do a relatively good job of predicting the observed values of tidal duration in the test dataset based on the included tidal characteristics in Figure 7. Refer to Tables 2 and 3 for more information.

Table 2. Summary of tidal duration multiple linear regression models. The training group used to design these models was comprised of $80 \%$ of the original dataset, and those models were applied to the remaining $20 \%$ of the original data (the test dataset) to determine the model fit. The number of observations was 488 for the training group and 122 for the test group. The reported residual standard errors (RSE) are in minutes. Tidal characteristics separated by a colon (e.g., "Baseflow Stage: Season" represent a significant interaction between the two factors.

\section{Significant Factors in Multiple Linear Regression Model \\ $\mathbf{R}^{2}$ Value of Model (Training Group) \\ RSE Value of Model (Training Group) \\ $\mathbf{R}^{2}$ Value of Test Group \\ RSE Value of Test Group}

\begin{tabular}{|c|c|c|c|c|c|}
\hline \multirow{9}{*}{$\begin{array}{l}\text { Flood/Incoming } \\
\text { Tide Duration }\end{array}$} & Tidal Range & \multirow{9}{*}{0.84} & \multirow{9}{*}{25 minutes } & \multirow{9}{*}{0.89} & \multirow{9}{*}{21 minutes } \\
\hline & Maximum Stage & & & & \\
\hline & Baseflow Stage & & & & \\
\hline & HT Cycle Factor & & & & \\
\hline & Seasonal Factor & & & & \\
\hline & Baseflow Stage : Season & & & & \\
\hline & Tidal Range : Max Stage & & & & \\
\hline & Tidal Range : Baseflow Stage & & & & \\
\hline & Max Stage : Baseflow Stage & & & & \\
\hline \multirow{9}{*}{$\begin{array}{l}\text { Ebb/Outgoing } \\
\text { Tide Duration }\end{array}$} & Tidal Range & \multirow{9}{*}{0.80} & \multirow{9}{*}{23 minutes } & \multirow{9}{*}{0.89} & \multirow{9}{*}{18 minutes } \\
\hline & Maximum Stage & & & & \\
\hline & Baseflow Stage & & & & \\
\hline & HT Cycle Factor & & & & \\
\hline & Seasonal Factor & & & & \\
\hline & Baseflow Stage : Season & & & & \\
\hline & Tidal Range : Max Stage & & & & \\
\hline & Tidal Range : Baseflow Stage & & & & \\
\hline & Max Stage : Baseflow Stage & & & & \\
\hline
\end{tabular}


Modeling Tidal Characteristics in a Creek-Marsh Drainage System

Table 3. Summary of model predictions compared to observed values for the flood and ebb tides. These observations and predictions apply to the entire original dataset; $n=610$.

\begin{tabular}{cccccccc}
\hline & & Min & Med & Max & Mean & Standard Deviation & Standard Error of the Mean \\
\hline \multirow{2}{*}{$\begin{array}{c}\text { Flood/Incoming } \\
\text { Tide Duration }\end{array}$} & Observations & 74 & 231 & 373 & 229 & 63 & 2.5 \\
\cline { 2 - 6 } & $\begin{array}{c}\text { Model } \\
\text { Predictions }\end{array}$ & 86 & 228 & 345 & 229 & 57 & 2.3 \\
\hline $\begin{array}{c}\text { Ebb/Outgoing } \\
\text { Tide Duration }\end{array}$ & \begin{tabular}{c} 
Observations \\
\cline { 2 - 6 }
\end{tabular} & 40 & 182 & 346 & 182 & 2.1 \\
\hline
\end{tabular}

show that the ditch is moving towards a tidally dominant system in an area that was originally an inland floodplain.

\section{IMPLICATIONS AND BROADER IMPACTS}

\section{TIDAL ASYMMETRY IN DRAINAGE DITCHES}

Observations from this study show that the tidal dynamics within the drainage ditch system are typical to the South Carolina coast, in that the tidal cycles are ebb dominant. These areas are defined as having longer flood/incoming tides and shorter ebb/outgoing tides. Ebb-dominant tidal systems also experience higher peak flow rates on the ebb tide than the flood tide. Data continue to be collected at the DC 01 monitoring site; preliminary results indicate that these characteristics hold true for the tidal drainage ditch as well.

This is a significant finding because there is a gap in research on understanding the dynamics of tidal flow within drainage ditches. It is known that changing the morphology of a system can affect water movement in the system and potentially change the asymmetry in the tides (Wang et al. 1999), but that this is at a case-by-case basis dependent on the specific water flow alterations (Tonjes 2013). Our results show that the drainage ditch within the Church Flats system fits the expected asymmetry of the South Carolina coast, which is important in determining potential nutrient and pollutant loading (Ellis et al. 2017) and sediment transport of the system (Hoitink et al. 2003). Further research should be done on similar systems to better understand if the impacts of ditching on tidal asymmetry can be applied across multiple systems in a region or if it is truly a case-by-case basis.

\section{IMPACT OF DITCHING ON TIDAL DYNAMICS AND HYDROLOGY} Results of the SLR simulations indicate that the tidal influence has increased in the ditch since its creation, from an average flood tide of $210 \pm 2.4$ minutes in 1993 to $229 \pm 2.3$ minutes in 2019. This is expected to increase to $295 \pm 2.0$ minutes by 2050 , meaning that the system will be dominated by tidal flow and there will be a longer delay in the release of stormwater and baseflow (Table 4).
This is a dramatic change from a system that was originally the headwaters of a small tidal creek, most likely a brackish floodplain where the tide dispersed over a wide area to a very shallow depth. The connection of this ditch has concentrated the tidal flow and has essentially created an artificial tidal-freshwater transitional zone. These transition zones are defined as the geomorphic area where the flow within a system changes from unidirectional (fluvial) to bidirectional (tidal) and is now present in an area that naturally had none (Yankovsky et al. 2012; Torres, 2017).

The geomorphology of transitional zones is difficult to replicate, as they are often defined by bedrock outcrops and a decrease in upstream width that aid in reducing the upstream tidal energy (Novakowski et al. 2004; Torres 2017). Bedrock is not exposed in the region studied here, however the specific morphology of the drainage ditch that is both wider and deeper than the natural headwaters of the connected tidal creek likely had an impact on the reach of the flood tide inland. It is expected that this impact would lessen if the morphology of the ditch system more closely resembled that of a natural transitional zone, which would exhibit higher levels of roughness. We posit that the construction of the ditch not only has allowed the tide to intrude further inland but also changed the hydrology of the surrounding landscape. A common practice in stormwater management is to dig ditches deeper in order to accommodate higher volumes of stormflow, but due to the shallow water tables in the area (typically $<2 \mathrm{~m}$ below ground), the depth of the ditch becomes irrelevant. Artificially lowering the elevation through ditching to intersect the water tables has lowered the water table of the surrounding area. In this watershed, more than $40 \%$ of the landscape is wetlands. This has resulted in the drainage ditch becoming a perennial stream that has baseflow (groundwater seepage) draining to the downstream tidal creek, especially during the winter months when the evaporation rate is small and the water balance is in surplus.

As the tidal flow reaches further inland and reverses the hydraulic gradient of the system, the baseflow (and stormflow, if runoff has occurred) is not able to leave the 


\section{Brown, Callahan}
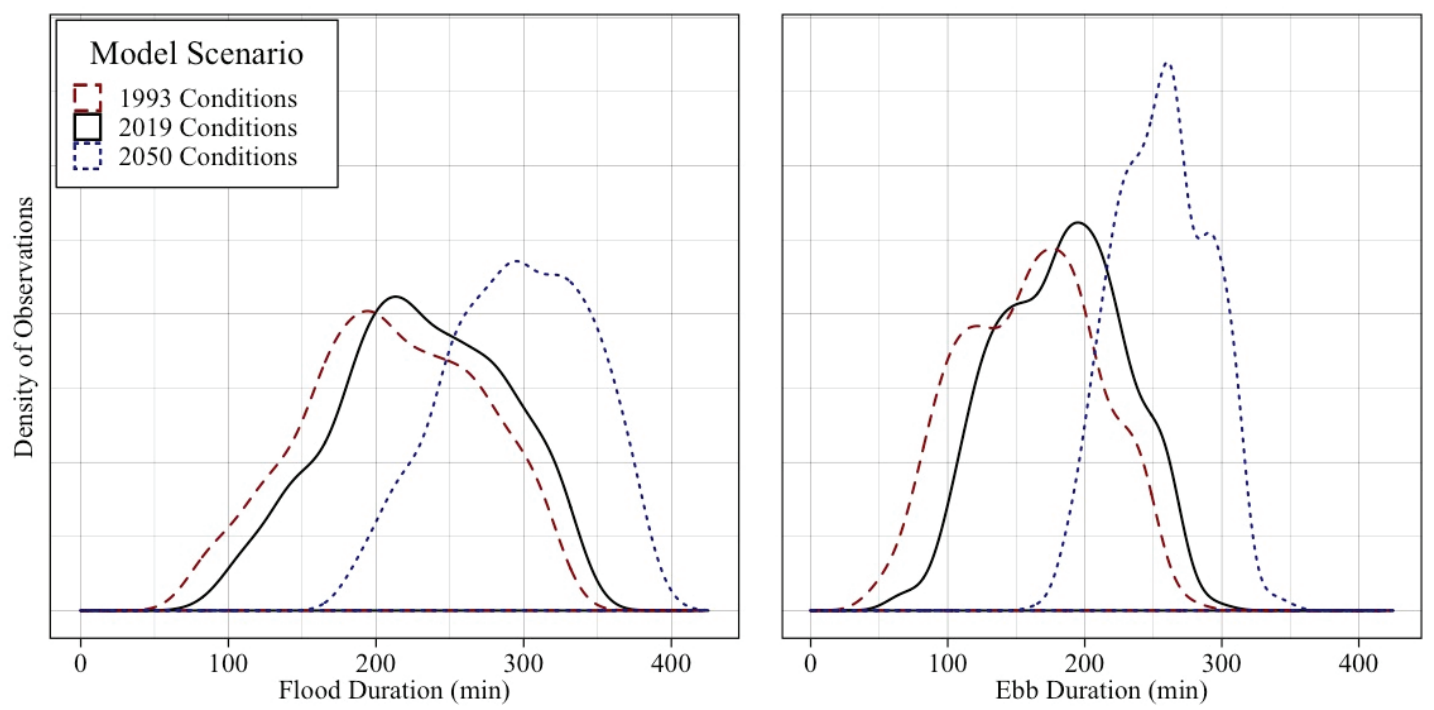

Figure 9. Flood and ebb tidal durations at the DC 01 monitoring location under difference scenarios of sea level rise. The 1993 scenario (dashed red line) is based on the average amount of sea level rise observed since then, 0.096 m (NASA 2019), and the 2050 scenario (dotted blue line) is based off of $0.422 \mathrm{~m}$ of SLR (SeaLevelRise.org). The current conditions (2019; solid black line) are displaying the model predictions instead of the actual observations (refer to Figure 8) for consistency across scenarios. To simulate these scenarios of SLR, the max stage and tidal range of the observations were altered according to the SLR scenario above, with the remaining predictive variables remaining constant. These scenarios were applied to 610 observations from January 2019-February 2020. Refer to Table 4 for more information.

system. This increase in water residence time can increase the risk of compound flooding events. Future sea level rise will exacerbate this effect.

\section{IMPLICATIONS FOR LAND USE}

The tidally-influenced stormwater ditch is at further risk for increased tidal intrusion due to development in the region. The Church Flats watershed is currently rural (2.01\% impervious surface cover), and if it begins to develop due to the growth of the greater Charleston area, increased impervious surfaces could lead to additional stormwater problems. A larger percentage of impervious cover would reduce groundwater infiltration (Harbor 1994; Erickson and Stefan 2009), which would thereby result in less baseflow to the ditch system. As these results show, baseflow stage is a strong determinant in the duration of the flood tide influence within the ditch and a reduction in baseflow to the ditched system could thereby lead to an increased tidal influence. As this site is predominantly wetland and forest, the amount of total runoff volume per storm event would be expected to increase (Amatya and Trettin 2007; Blair et al. 2014). Increased frequency of flood events should be taken into consideration when planning future development.

\section{CONCLUSIONS AND RECOMMENDATIONS}

Like in many locations across the southeastern U.S. coastal plain, decades ago a drainage ditch was constructed in a lowland watershed such that it discharges to the headwaters of a tidal creek in an effort to quickly divert stormwater to a receiving water body, but the connection of these systems has had unintended consequences. Such stormwater infrastructure now acts as a conduit for the incoming flood tide. This study shows that the tidal influence within the tidal creek-ditch system has increased with sea level rise (SLR) which is expected to continue in this region. The rising tidal influence within the ditch will reduce the efficacy of the ditch to properly relay stormwater runoff out of the system as designed.

The flood tide volumes observed in this analysis ranged an order of magnitude $\left(53-556 \mathrm{~m}^{3}\right)$, yet this volume was small compared to the theoretical volume of stormwater runoff in this 750-hectare watershed following rain events (more than $160,000 \mathrm{~m}^{3}$ ) as estimated from a curve number based model, SWARM (Blair et al. 2014). Furthermore, stormwater drainage would be affected by a smaller hydraulic gradient of the system, an expected result of sea level rise. The direct impact of multiple inputs on system response is currently being evaluated further, and it is recommended that continued research consider the impacts of ditching and flow restrictions on the sediment deposition within tidalditch systems.

One solution to prevent the further reduction of the hydraulic gradient in the system is to utilize the natural floodplains and wetlands of the area surrounding the headwaters of Church Flats Creek. Disconnecting the drainage ditch and the tidal creek would result in both stormwater runoff and tidal flow discharging into the currently bypassed 


\section{Modeling Tidal Characteristics in a Creek-Marsh Drainage System}

Table 4. Model results for different scenarios of sea level rise. Note that the 2019 values represent the model predictions of the observed variables rather than the actual observations of the flood and ebb tides for consistency when comparing to the 1993 and 2050 scenarios. The total mean tidal duration is the sum of the average flood and ebb tides. For reference, in this region a complete tidal cycle (flood + ebb tides) in a semidiurnal system should be approximately 745 minutes. The values from this model simulation indicate that the ditch-creek system has become more tidally influenced from SLR and is moving towards a completely tidal system. All values reported are in minutes.

\begin{tabular}{|c|c|c|c|c|c|c|c|c|}
\hline Year Modeled & Tide Duration & Min & Med & $\operatorname{Max}$ & Mean & $\begin{array}{l}\text { Standard } \\
\text { Deviation }\end{array}$ & $\begin{array}{c}\text { Standard Error } \\
\text { of the Mean }\end{array}$ & $\begin{array}{c}\text { Total Mean Tidal } \\
\text { Influence }\end{array}$ \\
\hline \multirow{2}{*}{1993} & Flood & 78 & 209 & 329 & 210 & 59 & 2.5 & \multirow{2}{*}{370} \\
\hline & Ebb & 44 & 162 & 281 & 160 & 49 & 2.0 & \\
\hline \multirow{2}{*}{2019} & Flood & 86 & 228 & 345 & 229 & 57 & 2.3 & \multirow{2}{*}{412} \\
\hline & Ebb & 62 & 185 & 299 & 183 & 46 & 1.9 & \\
\hline \multirow{2}{*}{2050} & Flood & 177 & 298 & 395 & 295 & 48 & 2.0 & \multirow{2}{*}{551} \\
\hline & Ebb & 166 & 257 & 349 & 256 & 33 & 1.4 & \\
\hline
\end{tabular}

floodplains. This strategy would prevent the incoming tide from moving further inland within the drainage network and would therefore not have a direct influence on the drainage system. This would also facilitate stormwater management within the watershed. For sites where large areas of floodplain are available for intra-watershed storage, we recommend landowners to assess different low impact development (LID) practices in order to mitigate the volume of stormwater and/ or extend the runoff duration period to reduce the peak flow rate on the water body receiving the runoff.

\section{REFERENCES}

Amatya DM, Trettin C. 2007. Annual evapotranspiration of a forested Wetland Watershed, SC. 2007 ASABE Annual International Meeting. Minneapolis, MN. ASABE Paper Number 072222. https//doi.org/10.13031/2013.22992.

Blair A, Lovelace S, Sanger D, Holland AF, Vandiver L, White S. 2014. Exploring impacts of development and climate change on stormwater runoff. Hydrological Process. 28(5):2844-2854. https//doi.org/10.1002/ hyp. 9840 .

Boone III, JD. 1975. Tidal discharge asymmetry in a salt marsh drainage system. Limnology and Oceanography. 20(1):71-80.

Brooks KN, Ffolliott PF, Magner JA. 2013. Hydrology \& the Management of Watersheds. 4th ed. Hoboken, NJ: WileyBlackwell.

Buchanan B, Easton ZM, Schneider RL, Walter MT. 2013. Modeling the hydrologic effects of roadside ditch networks on receiving waters. Journal of
Hydrology 486:293-305. https://doi.org/10.1016/j. jhydrol.2013.01.040.

Church JA, White NJ. 2006. A 20th century acceleration in global sea-level rise. Geophysical Research Letters. 33(1):94-97. https://doi.org/10.1029/2005GL024826.

Cotti-Rausch BE, Majidzadeh H, DeVoe MR. (eds.). 2019. Stormwater Ponds in Coastal South Carolina: 2019 State of Knowledge Full Report. S.C. Sea Grant Consortium, Charleston, S.C. SCSGC-T-20-02. https://www.scseagrant. org/stormwater-ponds-in-south-carolina-state-ofknowledge-report/.

D’Ambrosio JL, Ward AD, Witter JD. 2015. Evaluating Geomorphic Change in Constructed Two-Stage Ditches. Journal of the American Water Resources Association. 51(4):910-922. https://doi.org/10.1111/1752-1688.12334.

Dolan TJ, Hermann AJ, Bayley SE, Zoltek J. 1984.

Evapotranspiration of a Florida, U.S.A., freshwater wetland. Journal of Hydrology. 74:355-371. https://doi. org/10.1016/0022-1694(84)90024-6.

Ellis KK, Callahan TJ, Greenfield DI, Sanger D, Robinson J, Jones M. 2017. Measuring and modeling flow rates in tidal creeks: a case study from the central coast of South Carolina. Journal of South Carolina Water Resources. 4(1):21-39.

Erickson TO, Stefan HG. 2009. Natural groundwater recharge response to urbanization: Vermillion River watershed, Minnesota. Journal of Water Resources Planning and Management. 135(6):512-520. https://doi. org/10.1061/(ASCE)0733-9496(2009)135:6(512).

Fagherazzi S, Furbish DJ. 2001. On the shape and widening of salt marsh creeks. Journal of Geophysical Research: Oceans. 106(C1):991-1003. https://doi. org/10.1029/1999JC000115. 


\section{Brown, Callahan}

Fagherazzi S, Hannion M, D’Odorico P. 2008. Geomorphic structure of tidal hydrodynamics in salt marsh creeks. Water Resources Research. 44:1-12. https://doi. org/10.1029/2007WR006289.

Fischer EM, Knutti R. 2015. Anthropogenic contribution to global occurrence of heavy-precipitation and hightemperature extremes. Nature Climate Change. 5. https:// doi.org/10.1038/NCLIMATE2617.

Gray LJ, Ward J V. 1982. Effects of sediment releases from a reservoir on stream macroinvertebrates. Hydrobiologia. 96:177-184.

Gregory KJ, Davis RJ, Downs PW. 1992. Identification of river channel change to due to urbanization. Applied Geography. 12(4):299-318. https://doi.org/10.1016/01436228(92)90011-B.

Harbor JM. 1994. A practical method for estimating the impact of land-use change on surface runoff, groundwater recharge and wetland hydrology. Journal of the American Planning Association. 60(1):95-108. https://doi. org/10.1080/01944369408975555.

Hoitink AJF, Hoekstra P, Van Maren DS. 2003. Flow asymmetry associated with astronomical tides: Implications for the residual transport of sediment. Journal of Geophysical Research. 108(C10): 3315. https:// doi.org/10.1029/2002jc001539.

Hooper D, Coughlan J, Mullen MR, Mullen J, Hooper D, Coughlan J, Mullen MR. 2008. Structural equation modelling: guidelines for determining model fit. The Electronic Journal of Business Research Methods. 6(1):53-60. www.ejbrm.com.

Izagirre O, Serra A, Guasch H, Elosegi A. 2009. Effects of sediment deposition on periphytic biomass, photosynthetic activity and algal community structure. Science of the Total Environment. 407(21):5694-5700. https://doi.org/10.1016/j.scitotenv.2009.06.049.

Koch F, Gobler CJ. 2009. The effects of tidal export from salt marsh ditches on estuarine water quality and plankton communities. Estuaries and Coasts. 32(2):261-275. https://doi.org/10.1007/s12237-008-9123-y.

Lecce SA, Gares PA, Pease PP. 2006. Drainage ditches as sediment sinks on the coastal plain of North Carolina. Physical Geography. 27(5):447-463. https://doi. org/10.2747/0272-3646.27.5.447.

Lehmann J, Coumou D, Frieler K. 2015. Increased record-breaking precipitation events under global warming. Climatic Change. 132(4):501-515. https://doi. org/10.1007/s10584-015-1434-y.

Leopold LB, Huppman R, Miller A. 2005. Geomorphic effects of urbanization in forty-one years of observation. Proceedings of the American Philosophical Society. 149(3):349-371.

Magner J, Hansen B, Sundby T, Kramer G, Wilson B, Nieber J. 2012. Channel evolution of Des Moines Lobe till drainage ditches in southern Minnesota (USA). Environmental Earth Sciences. 67(8):2359-2369. https:// doi.org/10.1007/s12665-012-1682-3.
Merrifield MA, Merrifield ST, Mitchum GT. 2009. An anomalous recent acceleration of global sea level rise. Journal of Climate. 22(21):5772-5781. https://doi. org/10.1175/2009JCLI2985.1.

Moftakhari HR, AghaKouchak A, Sanders BF, Feldman DL, Sweet W, Matthew RA, Luke A. 2015. Increased nuisance flooding along the coasts of the United States due to sea level rise: Past and future. Geophysical Research Letters. 42(22):9846-9852. https://doi. org/10.1002/2015GL066072.

Moftakhari HR, Salvadori G, AghaKouchak A, Sanders BF, Matthew RA. 2017. Compounding effects of sea level rise and fluvial flooding. PNAS. 114(37):9785-9790. https:// doi.org/10.1073/pnas.1620325114.

Myrick RM, Leopold LB. 1963. Hydraulic Geometry of a Small Tidal Estuary. Physiographic and Hydraulic Studies of Rivers. Geological Survey Professional Paper 422-B.

NASA. 2019. Global Climate Change: Vital Signs of the Planet - Sea Level. https://climate.nasa.gov/vital-signs/ sea-level.

NOAA, Office for Coastal Management. 2010 C-CAP Regional Land Cover. Coastal Change Analysis Program (C-CAP) Regional Land Cover. Charleston, SC: NOAA Office for Coastal Management. Accessed at www.coast. noaa.gov/ccapftp.

NOAA Office for Coastal Management. 2020. Fast facts: South Carolina. https://coast.noaa.gov/states/southcarolina.html.

NOAA. 2019. Tides and Currents: Relative Sea Level Trend Charleston, SC. https://tidesandcurrents.noaa.gov/ sltrends/sltrends_station.shtml?id=8665530.

Novakowski KI, Torres R, Gardner LR, Voulgaris G. 2004. Geomorphic analysis of tidal creek networks. Water Resources Research 40:W05401.

Perillo GME. 2009. Tidal Courses: Classification, Origin and Functionality. In: Perillo GME, Wolanski E, Cahoon DR, Brinson MM, editors. Coastal Wetlands: An Integrated Ecosystem Approach. 1st ed. Elsevier. p. 185-209.

Poole GC, Berman CH. 2001. An ecological perspective on in-stream temperature: Natural heat dynamics and mechanisms of human-caused thermal degradation. Environmental Management. 27(6):787-802. https://doi. org/10.1007/s002670010188.

Poulter B, Goodall JL, Halpin PN. 2008. Applications of network analysis for adaptive management of artificial drainage systems in landscapes vulnerable to sea level rise. Journal of Hydrology. 357:207-217. https://doi. org/10.1016/j.jhydrol.2008.05.022.

R Core Team. 2017. R: A language and environment for statistical computing. R Foundation for Statistical Computing, Vienna, Austria. URL https://www.R-project. org.

S.C. Department of Health and Environmental Control [SCDHEC]. 2018. The State of South Carolina's 2018 Integrated Report (IR) Part I: Listing of Impaired Waters. 
S.C. Sea Grant Consortium [SCSGC]. 2020. About Coastal South Carolina. https://www.scseagrant.org/southcarolina-coast/.

Sanger D, Blair A, DiDonato G, Washburn T, Jones S, Riekerk G, Wirth E, Stewart J, White D, Vandiver L, et al. 2015. Impacts of Coastal Development on the Ecology of Tidal Creek Ecosystems of the US Southeast including Consequences to Humans. Estuaries and Coasts. 38:4966. doi:0.1007/s12237-013-9635-y.

SeaLevelRise.org. [date unknown]. South Carolina. https:// sealevelrise.org/states/south-carolina.

Semadeni-Davies A, Hernebring C, Svensson G, Gustafsson LG. 2008. The impacts of climate change and urbanisation on drainage in Helsingborg, Sweden: suburban stormwater. Journal of Hydrology. 350:114-125. https:// doi.org/10.1016/j.jhydrol.2007.11.006.

Soil Survey Staff, Natural Resources Conservation Service, United States Department of Agriculture. Web Soil Survey. Available online at https://websoilsurvey.nrcs. usda.gov/. Accessed 11/01/2020.

Sweet W V., Park J. 2014. From the extreme to the mean: Acceleration and tipping points of coastal inundation from sea level rise. Earth's Future. 2:579-600. https://doi. org/10.1002/2014EF000272.

Tonjes DJ. 2013. Impacts from ditching salt marshes in the mid-Atlantic and northeastern United States. Environ Reviews. 21(2):116-126. https://doi.org/10.1139/er-20130003.

Torres R. 2017. Channel geomorphology along the fluvial-tidal transition, Santee River, USA. GSA Bulletin 129(11):1681-1691. https://doi.org/10.1130/b31649.1.

Wang H, Fu R, Kumar A, Li W. 2010. Intensification of summer rainfall variability in the southeastern United States during recent decades. Journal of Hydrometeorology. 11(4):1007-1018. https://doi. org/10.1175/2010JHM1229.1.

Wang Z, Jeuken, C, de Vriend, HJ. 1999. Tidal asymmetry and residual sediment transport in estuaries. TU Delft (Netherlands) Hydraulics, available at https://repository. tudelft.nl/islandora/object/uuid:08911ef5-5ee8-4a8b9432-5a5a5dfaa142/datastream/OBJ/download.

Yankovsky AE, Torres R, Torres-Garcia LM, Jeon K. 2012. Interaction of tidal and fluvial processes in the transition zone of the Santee River, SC, USA. Estuaries and Coasts. 35(6):1500-1509. https://doi.org/10.1007/s12237-0129535-6. 